\title{
Oxidative Stress Mediated Dose-Dependent Pathophysiological Alterations in Liver, Kidney, Heart and Intestine of Rats Exposed to Different Levels of Cadmium Chloride
}

\author{
S.S. Rao, C.N. Makwana, U.D. Patel*, V.C. Ladumor, H.B. Patel and C.M. Modi \\ Department of Veterinary Pharmacology and Toxicology, College of Veterinary Science and \\ AH, Junagadh Agricultural University, Junagadh-362001, Gujarat, India \\ *Corresponding author
}

\section{Keywords}

Cadmium chloride, Subacute toxicity, Male rats, Oxidative stress markers

Article Info

Accepted:

04 December 2018

Available Online:

10 January 2019

\section{A B S T R A C T}

Present study was carried out to evaluate toxic effect of cadmium chloride at 15, 50 and $100 \mathrm{ppm}$ in drinking water for 28 days on liver, kidney, heart and intestine in male rats. Twenty-four male albino rats ( 270 to $340 \mathrm{~g}$, 4 weeks of age) were randomly divided in to 4 groups having 6 animals in each group. The animals of control group received distilled water throughout the experimental period, while rats of other three groups received either 15,50 or $100 \mathrm{ppm}$ of $\mathrm{CdCl}_{2}$ in drinking water for consecutive 28 days. Haematological and biochemical parameters, histopathological evaluation and status of oxidative stress markers were observed at the end of study. Alterations in ALT, AST, AKP and BUN of rats of all three toxic groups were dose dependant. SOD activity $(\mathrm{U} / \mathrm{mL})$ was significantly increased $(\mathrm{p}<0.05)$ in serum and liver while decreased in kidney and intestine of all toxic groups as compared to control. Activity of catalase in blood (molar/min) was significantly decreased $(\mathrm{p}<0.05)$ in all groups as compared to control. Catalase activity (U/mg protein) in liver, heart and intestine were significantly decreased as compared to control in dose dependant way. However, significant decrease in catalase activity was observed in kidney at high level of exposure to cadmium. The level of $\mathrm{GSH}(\mu \mathrm{g} / \mathrm{mg}$ of tissue) was significantly decreased in tissues at higher level of exposure. Histopathological analysis revealed that liver, kidney, heart and intestine showed changes in dose dependent manner. In conclusion, cadmium at $100 \mathrm{ppm}$ caused marked alterations to multiple organs through oxidative damage in rats following continuous exposure for 28 days.

\section{Introduction}

Cadmium (Cd) is listed in top hazardous substances which are used in nickel- cadmium batteries, pigments and plastic stabilizers. Major occupational exposures to $\mathrm{Cd}$ occur in nonferrous metal smelters, production and processing of $\mathrm{Cd}$ alloys and compounds
(WHO, 1992; Fay and Mumtaz, 1996). Cigarette smoke is also the source of $\mathrm{Cd}$ exposure to humans (Zalups and Ahmad, 2003). It is well known that long-term exposure to $\mathrm{Cd}$ causes various toxic effects in various organs such as heart, kidneys, liver, brain, lung, bones, haemopoietic organs, endocrine and reproductive organs (Fowler, 
2009; Satarug et al., 2010; Cuypers et al., 2010). There is a positive correlation between $\mathrm{Cd}$ exposure and an augmented risk for cardiovascular diseases (Everett and Frithsen, 2008; Peters et al., 2010).

Cd may be deposited in the heart muscle and produce cardiotoxicity at as low as $0.1 \mu \mathrm{M}$ concentration (Limaye and Shaikh, 1999). Cadmium enhances the production of free radicals and interferes with the antioxidant defence system which in turn leads to a cadmium induced alterations in the structural integrity of lipids and secondarily affects the membrane bound enzymes (Shukla et al., 1996).

Cd accumulates mainly in the liver and to a lesser extent in the kidney and other tissues. In all tissues, $\mathrm{Cd}$ induces and binds to metallothionein (MT) and is stored as a nontoxic CdMT complex (Webb, 1986). CdMT is translocated from liver to kidneys due to normal turnover of hepatocytes as well as hepatic injury (Dudley et al., 1985; Chan et al., 1993).

Investigations also demonstrated that cadmium exposure increased oxidative stress, endocrine disruption and increased apoptosis in rabbit, dog and calf stallion (Waalkes, 2000; Siu et al., 2009).

Various studies demonstrated specific organ toxicity due to exposure to particular level of cadmium in rodent. The effect of cadmium exposure at different levels on liver, kidney, heart and intestine has not been studied with special reference to oxidative damage.

Thus, the present study was carried out to evaluate the sub-acute toxic effect of cadmium at low (15 ppm), medium (50 ppm) and high (100 ppm) level exposure on different organs in rats with special attention to oxidative stress mediated changes.

\section{Materials and Methods}

\section{Chemicals}

Cadmium chloride was purchased from Himedia, Mumbai (Lot No: 0000298204). The chemicals like $\mathrm{KH}_{2} \mathrm{PO}_{4}$ (Lot No: I12A/3212/0907/53) and $\mathrm{Na}_{2} \mathrm{HPO}_{4} \cdot 2 \mathrm{H}_{2} \mathrm{O}$ (Lot No: K14A/0514/2104/31) were purchased from S.D. fine Chemicals, Mumbai. Other chemicals like RBC lysis buffer (Lot No: RNBG5300), Pyrogallol (Lot No: 1002139642), dTNB (Lot No: SHBG1688V) and Bradford reagent (Lot No: SLBV5669) of analytical grade were purchased from Sigma Aldrich, USA. EDTA (Lot No: 61803701001730) and $\mathrm{H}_{2} \mathrm{O}_{2}$ (Lot No: CE6C660325) were purchased from Merck Ltd., Mumbai.

\section{Experiment animals and design}

The study was conducted on 24 albino rats (270-340 g weight, 4 weeks of age). The rats were acquired from registered breeder. The experimental was approved by the Institutional Animal Ethics Committee (IAEC), College of Veterinary Science and Animal Husbandry, Junagadh Agricultural University, Junagadh, Gujarat (JAU/JVC/IAEC/SA/32/18).

The rats were maintained in standard polypropylene cages with stainless steel top grill and Corn Cobb was used as bedding material. During whole study period, feed and water were supplied ad libitum. Rats were accommodated in cool environment $\left(23^{\circ}\right.$ to $27^{\circ} \mathrm{C}$ ) with relative humidity ranged between 42 to $55 \%$ along with 12 hours light-dark cycle. The rats were randomly divided to four groups (six rats in each group). The first group was received the ad libitum drinking water for a period of 28 days and it served as a control. The rats of group II, III and IV were exposed to cadmium chloride at 15,50 and $100 \mathrm{ppm}$ 
respectively through drinking water for the period of 28 days. All animals were given feed (VRK Nutritional Solutions, Maharashtra) ad libitum throughout the study period.

\section{Collection of samples}

Blood sample from each rat was collected from retro-orbital plexus under light anaesthesia on day 29 for evaluation of haematological, biochemical and oxidative stress parameters. All rats were humanely sacrificed at the end of study to observe gross pathological changes in organs and the tissues of major organs like liver, kidney, heart and intestine were collected in $10 \%$ formalin for histopathological examination. The tissue samples of liver, kidney, heart and intestine were collected and homogenized in $10 \%$ phosphate buffer (7.5 pH; PBS: $\mathrm{KH}_{2} \mathrm{PO}_{4}$ and $\mathrm{Na}_{2} \mathrm{HPO}_{4} \cdot 2 \mathrm{H}_{2} \mathrm{O}$ ) and centrifuged at $12000 \mathrm{~g}$ for 5 minutes and resulted supernatant was used for estimation of various antioxidant enzymes except for SOD in which Tris-EDTA buffer (8.2-8.5 pH) was used and centrifuged at $12000 \mathrm{~g}$ for 40 minutes. Weight of liver, kidney, heart, spleen and lung were recorded using analytical balance (Model: Sartorius, BSA-423SCW) to calculate the relative organ body weight ratio.

\section{Body weight and feed consumption}

During experimental period, body weight of each rat was observed daily. The feed offered to each group was accurately recorded daily in the morning. The residual feed given day before was accounted. Based on these data, amount of feed consumed by rats of each group was calculated.

\section{Haematological and biochemical evaluation}

Haematological parameters like hemoglobin $(\mathrm{Hb})$, packed cell volume (PCV), total erythrocyte count (TEC), total leucocyte count
(TLC), differential leukocyte count (DLC), mean corpuscular volume (MCV), mean corpuscular hemoglobin concentration (MCHC) and mean corpuscular hemoglobin $(\mathrm{MCH})$ were estimated by using automated haematology analyzer (Abacus Junior Vet 5, Diatron, Hungary) at Department of Veterinary Pathology, Junagadh Agricultural University, Junagadh.

Biochemical parameters like alanine aminotransferase (ALT), aspartate aminotransferase (AST), alkaline phosphatase (AKP), lactate dehydrogenase (LDH), blood urea nitrogen (BUN), uric acid, total protein (TP), albumin and globulin were estimated by using standard kits (Diatek Health Care Pvt. Ltd, India) on semi-automatic biochemistry analyser (Diatek Health Care Pvt. Ltd, India).

\section{In vivo antioxidant activity}

\section{Preparation of blood lysate for catalase and GSH}

Each blood sample $(50 \mu \mathrm{L})$ was mixed with $450 \mu \mathrm{L}$ of RBC lysis buffer (Sigma Aldrich, Lot No. RNBG0536) and kept for 5 minutes for efficient lysis of erythrocytes. The resultant blood lysate was used for evaluation of catalase activity and glutathione (GSH) level.

\section{Preparation of tissue samples for SOD, catalase and GSH}

Samples of liver, kidney, heart and intestine (100 mg each) were collected from all rats and immediately stored in $1 \mathrm{~mL}$ ice cold $0.1 \mathrm{M}$ phosphate buffer saline (PBS: $\mathrm{KH}_{2} \mathrm{PO}_{4}$ and $\mathrm{Na}_{2} \mathrm{HPO}_{4} \cdot 2 \mathrm{H}_{2} \mathrm{O}, \mathrm{pH}:$ 7.5) for evaluation of catalase activity and GSH level, whereas samples of liver, kidney, intestine and heart $100 \mathrm{mg}$ each were separately collected in TrisEDTA buffer (pH: 8.5) for analysis of SOD activity. Manual homogenizer was used to 
prepare the tissue homogenates which then centrifuged at $12000 \mathrm{~g}$ at $4{ }^{\circ} \mathrm{C}$ for 10 minutes except for SOD in which centrifugation was done at $12000 \mathrm{~g}$ for 40 minutes and supernatant was used for evaluation of catalase activity, GSH level and SOD activity. Protein estimation in liver, kidney, intestine and heart was carried out using the standard method (Bradford, 1976). These data were used to calculate catalase activity in liver, kidney, heart and intestine.

\section{Evaluation of SOD activity in serum and tissues (Inhibition of pyrogallol autoxidation method)}

Serum $(\mathrm{Cu}-\mathrm{Zn})$ SOD activity in serum and tissue homogenates was determined using a simple and rapid method, based on the ability of the enzyme to inhibit the autoxidation of pyrogallol (Marklund and Marklund, 1974).

The $2900 \mu \mathrm{L}$ Tris-EDTA and $100 \mu \mathrm{L}$ pyrogallol (2mM for tissue sample; $20 \mathrm{mM}$ for serum) were taken in the cuvette and scanned for 3 minutes at $420 \mathrm{~nm}$ wavelength as control reading in spectrophotometer (FusiontekUV2900). Then, $2890 \mu \mathrm{L}$ of Tris-EDTA buffer (pH-8.5), $100 \mu \mathrm{L}$ of pyrogallol and $10 \mu \mathrm{L}$ of tissue homogenate or $100 \mu \mathrm{L}$ of serum were taken and scanned for 3 minutes at the same wavelength.

Absorbance per 2 minutes difference was determined. One unit of SOD activity is the amount of the enzyme that inhibits the rate of auto oxidation of pyrogallol by $50 \%$. $(\mathrm{Cu}-\mathrm{Zn})$ SOD activity was expressed as units $/ \mathrm{mL}$ for serum sample and for tissue sample as $\mathrm{U} / \mathrm{mg}$ of tissue.

The enzyme unit can be calculated by using the following equations:

$\%$ of inhibition $=\frac{(A-B) \times 100}{B}$
Enzyme unit $(\mathrm{U})=(\%$ of inhibition $/ 50)$

*common dilution factor (100) [50\% inhibition $=1 \mathrm{U}]$

\section{Evaluation of catalase activity in blood and} tissue

Catalase activity in blood and tissue sample was determined according to the method of Aebi et al. (1974). The $20 \mu \mathrm{L}$ blood lysate (or $20 \mu \mathrm{L}$ of supernatant of tissue homogenate) was added to $1980 \mu \mathrm{L}$ PBS (0.1 M PBS, $\mathrm{pH}$ 7.5) in a test tube. One $\mathrm{mL}$ of $30 \mathrm{mM} \mathrm{H}_{2} \mathrm{O}_{2}$ was added to it and absorbance of reaction mixture was taken at $240 \mathrm{~nm}$ in a spectrophotometer for 1 minute, against blank having mixture of PBS and blood lysate or tissue homogenate only. Unit activity of catalase in blood was expressed in molar/minute. The activity of catalase from tissue samples was calculated using the molar extinction coefficient of $43.6 \mathrm{~cm}^{-1}$.

momoles of $\mathrm{H}_{2} \mathrm{O}_{2}$ deconposed/minute/mg protein $=\frac{\Delta A / \min \times 1000 \times 3}{43.6 \times \mathrm{m} \text { mg protein in sample }}$

\section{Estimation of GSH in blood and tissue samples}

The levels GSH in blood and tissue were estimated according to standard method (Ellman, 1959). Blood lysate $(10 \mu \mathrm{L})$ was mixed with $2970 \mu \mathrm{L}$ of PBS (0.1 M PBS, pH $7.5)$ in a test tube. dTNB $(30 \mathrm{mM})(20 \mu \mathrm{L})$ was added into it and the mixture was allowed to stand for reaction up to 45 minutes. Then, absorbance was taken at $412 \mathrm{~nm}$ against blank having mixture of PBS and blood lysate only without dTNB using spectrophotometer. Concentration of GSH was expressed in molar.

To estimate the levels GSH from tissue (liver, kidney, heart and intestine), $0.5 \mathrm{~mL}$ of tissue homogenate was taken and added with equal volume of $20 \%$ trichloroacetic acid (TCA) 
containing $1 \mathrm{mM}$ EDTA for precipitation of proteins. The mixture was allowed to stand for 5 min prior to centrifugation for 10 minutes at $12000 \mathrm{~g}$. The supernatant $(200 \mu \mathrm{L})$ was then transferred to a new set of test tubes and added with $1.8 \mathrm{~mL}$ of the Ellman's reagent $(5,5$ dithiobis-2-nitrobenzoic acid $(0.1 \mathrm{mM})$ prepared in $0.1 \mathrm{M}$ phosphate buffer with $1 \%$ of sodium citrate solution). All test tubes were made up to the volume of $2 \mathrm{~mL}$. After completion of the total reaction, absorbance of each set of mixture was measured at $412 \mathrm{~nm}$ against blank having mixture of PBS and supernatant. Absorbance values were compared with a standard curve to know concentration of GSH. Various standards ranged from 1 to $6 \mu \mathrm{g} / \mathrm{mL}$ were prepared and used to get standard graph by using the values of absorbance which was used to know the concentration of GSH in tissue homogenate. The blood GSH level was expressed in molar and calculated using the formula given below.

GSH (molar) = Absorbance (A)XTotal reaction volume 13600 Xsample volume

\section{Estimation of malondialdehyde (MDA)} level from plasma (Lipid peroxidation)

Lipid peroxidation was measured as a malondialdehyde (MDA) level using the standard kit (Sigma Aldrich, Germany) (Lot No: 3L08K07390).

\section{Histopathology}

The formalin fixed tissues of liver, kidney, heart and intestine were embedded in paraffin and processed as per standard procedures. These tissue samples were sectioned at $6-8 \mu$ thickness with semi-automated rotary microtome (Leica Biosystems, Germany) and were stained with haematoxylin and eosin $(\mathrm{H}$ \& E) stain (Luna, 1968). The H \& E stained slides were observed under microscope and microscopic pathological lesions were recorded.

\section{Statistical analysis}

Numerical data obtained from this study have been expressed as mean \pm standard error (SE). Data were analyzed statistically by ANOVA and mean of different treatment groups means were compared by Duncan's multiple range tests (DMRT) to observe difference among the treatments (Snedecor and Cochran, 1980).

\section{Results and Discussion}

\section{Feed consumption and body weight}

During $1^{\text {st }}$ week, feed consumption was significantly decreased $(\mathrm{P}<0.05)$ in animals exposed to 50 and $100 \mathrm{ppm}$ of cadmium as compared to those of control group (Figure 1). During the $2^{\text {nd }}$ week of exposure, animal exposed to only $100 \mathrm{ppm}$ cadmium showed significant reduced feed consumption. However, values of feed consumption during $3^{\text {rd }}$ and $4^{\text {th }}$ week in animals exposed to all 3 levels of $\mathrm{Cd}$ were not significantly differ as compared to control animals which might be due to acclimatization of body of animals with exposure to cadmium. The mean value of average body weight of animals of all 3 toxic groups were significantly decreased dose dependently $(\mathrm{P}<0.05)$ after 2 weeks of exposure to cadmium as compared to that of control group (Figure 2).

\section{Haematological and biochemical parameters}

The mean value of $\mathrm{Hb}, \mathrm{PCV}, \mathrm{TLC}, \mathrm{MCV}$, $\mathrm{MCHC}$ and $\mathrm{MCH}$ were significantly decreased $(\mathrm{P}<0.05)$ in animals exposed to medium and high level of $\mathrm{Cd}$ as compared to those observed in animals of control group (Table 1). The mean values of AST and AKP were significantly increased in treatment 
groups in dose dependent manner as compared to those of control group. The mean values of ALT were significantly lower $(\mathrm{P}<0.05)$ in 15 and $50 \mathrm{ppm}$ groups but in high dose (100 ppm) group, it was significantly higher as compared to that of control group. The mean values of BUN were significantly affected in all 3 toxic groups. However, levels of uric acid were significantly higher in higher level of exposure as compared to control (Table 2).

\section{Antioxidant enzymes}

The mean values of SOD activity in blood of animals exposed to different levels of $\mathrm{Cd}$ were similar but they were significantly higher $(\mathrm{P}<0.05)$ than that observed in control animals (Table 3). Mean values of SOD activity in kidney, intestine and heart significantly decreased $(\mathrm{P}<0.05)$ in all treatment groups $(15,50,100 \mathrm{ppm})$ as compared to control groups. But in liver, SOD activity was significantly increased at higher level of exposure (50 and $100 \mathrm{ppm}$ ) as compared to control groups.

The mean values of catalase activity in blood of animals exposed to $\mathrm{Cd}$ were significantly decreased $(\mathrm{P}<0.05)$ according to level of exposure as compared to the control group (Table 4). The mean values of catalase activity in tissue samples of intestine and heart were significantly decreased as compared to control group. The kidney tissue catalase activity in animals exposed to only high level of cadmium (T4) was significantly decreased as compared to control group. The catalase activity of tissue samples of liver significant decreased in animals exposed to higher level of $\mathrm{Cd}$ (50 and $100 \mathrm{ppm})$.

The mean values of serum GSH levels in rats exposed to all 3 levels of $\mathrm{Cd}$ were significantly decreased as compared to that of control animals (Table 5). In liver and kidney levels of GSH were significantly decreased particularly on higher dose level. Levels of GSH in intestine of animals exposed to all 3 levels of exposure were significantly lower as compared to that of control animals. The level of GSH in heart of animals exposed to lowest level of Cd was significantly increased.

\section{Malondialdehyde concentration (MDA)}

The mean value of plasma MDA concentration $(\mathrm{nmol} / \mu \mathrm{L})$ in rats exposed to 15 , 50 and $100 \mathrm{ppm}$ of $\mathrm{Cd}$ level were $21.74 \pm$ $6.18,26.74 \pm 5.84$ and $34.20 \pm 13.60$, respectively which were significantly higher $(\mathrm{P}<0.05)$ as compared to the value of $17.94 \pm$ $2.42(\mathrm{nmol} / \mu \mathrm{L})$ observed in control animals (Figure 3). The levels of plasma MDA were significantly increased dose dependently after exposure to all tested levels of cadmium.

\section{Histopathological changes}

Histopathological evaluation of liver, kidney, heart and intestine were carried out to evaluate the toxic effect of cadmium chloride. In liver, the changes were vacuolar degeneration, widening of sinusoids at $15,50 \mathrm{ppm}$ level of exposure. But at $100 \mathrm{ppm}$ level of exposure, the liver showed necrosis of hepatocytes, fragmentation of nuclei, pyknotic nuclei and widening of sinusoids (Figure 4). The kidney showed alterations in normal architecture with degenerative changes in glomeruli, proximate convoluted tubule, necrosis of glomeruli and denudation of bowmen capsule segments in a dose dependent manner (Figure 5). In intestine, $\mathrm{Cd}$ showed toxic effect in dose dependent manner with degenerative changes in villi, atrophy of intestinal glands, muscularis mucosa and lamina propria (Figure 6). Heart showed mild degenerative changes of cardiac muscle fibers at low level of exposure but perivascular fibrosis, hemorrhagic lesion and early focal necrosis at higher exposure level (Figure 7). Histopathological changes in all organs were more at 50 and $100 \mathrm{ppm}$ exposure groups compared to low level of exposure to cadmium. 
Environmental toxicant like cadmium may produce a variety of clinical manifestations. In man and animals, several organ systems, including the urinary, hepatic, nervous, reproductive, digestive and immune system may get affected. The heavy metals have potential towards production of the highly reactive chemical entities such as free radicals which have ability to cause lipid peroxidation, DNA damage, oxidation of sulfhydryl groups of proteins, depletion of protein, and several other effects (Valko et al., 2015)

In the present study, there was significant decrease in mean values of $\mathrm{Hb}, \mathrm{PCV}$, TLC, $\mathrm{MCV}, \mathrm{MCHC}$ and $\mathrm{MCH}$ in all treatment groups as compared to those of control group. According to previous study, anaemia has been reported in rats exposed to cadmium (Yuan et al., 2014). The anemia is result of accumulation of non-essential toxic metal in haematopoitic organs like kidney, liver and spleen (Gill and Epple, 1993). Moreover, the anemia is also resulted due the destruction of erythrocytes because of altered erythrocyte membrane permeability and fragility or due to the failure of iron uptake through intestine having mucosal lessions upon cadmium exposure (Pawaiya et al., 1998; Horiguchi et al., 2011). Histopathological examination of intestine confirmed that there was more damage to intestinal architecture due to direct toxic effect of cadmium in our study. High oxidative stress in red blood cells of cadmium exposed animals can account for the increase in metHb\% produced through $\mathrm{HbO} 2-$ autoxidation reactions (Waltkins et al., 1985). Thus, the inactive components of $\mathrm{Hb}(\mathrm{SHb}$, metHb and $\mathrm{HbCO}$ ) are unable to transport oxygen and interferes the normal physiological process of the body. In addition, the reduction in the blood parameters $(\mathrm{PCV}$, $\mathrm{RBC}$ and $\mathrm{Hb}$ ) may be attributed to hyperactivity of bone marrow that leading to production of red blood cells with impaired integrity that easily destructed in the circulation (Tung et al., 1975).
Liver and kidneys are considered as the main targets of $\mathrm{Cd}$ induced toxicity (Tondon et al., 2003). In the present study, the results showed increase in plasma AST activities which indicate an active transamination of amino acids and operation of keto acids which are probably fed into tricarboxylic acid cycle (TCA) for oxidation (Knox and Greengard, 1965). The decrease in ALT activities may be due to liver damage and disturbance in the synthesis of these enzymes (Rana et al., 1996). As in our study, significant changes in alkaline phosphatase (AKP) in cadmium treated groups compared with that of the control group were also reported (Ashour, 2014). This elevation could be attributed to liver damage which included swelling and ruptured parenchymal cell, leukocyte infiltration and necrosis (Quig, 1998).

The enzymatic antioxidant defence system includes mainly SOD, CAT and GSH which protect cells against reactive oxygen species (ROS) induced toxicity and lipid peroxidation. SOD converts the superoxide anion radical to hydrogen peroxide and CAT cleaves this hydrogen peroxide into water and oxygen. But heavy metals like $\mathrm{Cd}$ has adverse effect on numerous tissues through oxidative stress by increasing lipid peroxidation and fluctuating the antioxidant status (Ognjanovic et al., 2003; Sinha et al., 2008; Kanter et al., 2009). In our study, we observed a markedly decrease in SOD, CAT and GSH in majority of organs of rats exposed to $\mathrm{Cd}$ and along with a significant increase in lipid peroxidation as indicated by significant high MDA level (dose dependently). Interestingly, there was no significant alteration in level of GSH in blood, liver and kidney of animals exposed to the low level of $\mathrm{Cd}$ as compared to that of control group. The level of GSH in heart of animals exposed to lowest level of $\mathrm{Cd}$ was significantly increased. However, the GSH level in intestine at all tested levels of exposure was significantly lower as compared 
to that of control animals, which indicates variation in level of GSH in different organs which probably depends on activity of SOD and catalase in particular condition. Intracellular accumulation of $\mathrm{Cd}$ induces oxidative stress leading to cellular damage via displacement of redox-active metals, depletion of redox scavengers, inhibition of anti-oxidant enzymes and inhibition of the electron transport chain resulting in mitochondrial damage (Nair et al., 2013; Adiele et al., 2012; Patra et al., 2011). Cadmium has been documented to impact the body system damage through inhibition of antioxidant enzymes and induce oxidative damage with ROS generation which destroy proteins, lipids and DNA by oxidation.

Table.1 Haematological parameters in rats of different groups

\begin{tabular}{|c|c|c|c|c|}
\hline \multirow[t]{2}{*}{ Parameters } & \multicolumn{4}{|c|}{ Treatment groups } \\
\hline & Control & 15 ppm (T1) & 50 ppm (T2) & 100 ppm (T3) \\
\hline $\mathrm{HB}(\mathrm{g} / \mathrm{dL})$ & $15.35 \pm 0.29^{c}$ & $15.17 \pm 0.30^{c}$ & $14.27 \pm 0.41^{\mathrm{a}}$ & $14.93 \pm 0.28^{b}$ \\
\hline PCV (\%) & $42.68 \pm 1.13^{c}$ & $42.09 \pm 0.57^{b c}$ & $40.71 \pm 0.84^{\mathrm{a}}$ & $41.91 \pm 0.69^{b}$ \\
\hline TEC $\left(10^{6} /\lceil 1)\right.$ & $8.85 \pm 0.23^{b}$ & $8.72 \pm 0.11^{\mathrm{a}}$ & $8.65 \pm 0.18^{\mathrm{a}}$ & $8.92 \pm 0.15^{b}$ \\
\hline TLC $\left(10^{3} / \mathrm{cmm}\right)$ & $12.16 \pm 1.04^{\mathrm{c}}$ & $10.35 \pm 0.48^{b}$ & $10.30 \pm 0.88^{b}$ & $9.30 \pm 0.78^{a}$ \\
\hline MCV (fl) & $48.67 \pm 0.49^{c}$ & $48.33 \pm 0.33^{c}$ & $47.00 \pm 0.73^{\mathrm{a}}$ & $47.50 \pm 0.67^{b}$ \\
\hline $\mathrm{MCHC}(\%)$ & $36.02 \pm 1.64^{c}$ & $36.10 \pm 2.93^{c}$ & $35.05 \pm 3.52^{\mathrm{a}}$ & $35.63 \pm 1.95^{b}$ \\
\hline $\mathrm{MCH}(\mathrm{pg})$ & $17.50 \pm 3.69^{c}$ & $17.35 \pm 5.86^{\mathrm{c}}$ & $16.48 \pm 3.28^{\mathrm{a}}$ & $16.75 \pm 4.85^{b}$ \\
\hline
\end{tabular}

Value with different superscripts in a row were significantly different $(\mathrm{P}<0.05)$

Table.2 Biochemical parameters in rats of different groups

\begin{tabular}{|c|c|c|c|c|}
\hline \multirow{2}{*}{ Parameters } & \multicolumn{4}{|c|}{ Treatment groups } \\
\cline { 2 - 5 } & Control & $15 \mathrm{ppm}(\mathrm{T} 1)$ & $50 \mathrm{ppm}(\mathrm{T} 2)$ & $100 \mathrm{ppm}(\mathrm{T} 3)$ \\
\hline ALT $(\mathrm{IU} / \mathrm{L})$ & $59.40 \pm 8.42^{\mathrm{c}}$ & $46.90 \pm 2.62^{\mathrm{a}}$ & $54.00 \pm 4.80^{\mathrm{b}}$ & $60.66 \pm 8.39^{\mathrm{c}}$ \\
\hline AST (IU/L) & $123.50 \pm 14.19^{\mathrm{a}}$ & $147.64 \pm 5.76^{\mathrm{b}}$ & $156.95 \pm 8.58^{\mathrm{c}}$ & $219.74 \pm 13.71^{\mathrm{d}}$ \\
\hline AKP (IU/L) & $134.43 \pm 9.40^{\mathrm{a}}$ & $168.10 \pm 13.17^{\mathrm{b}}$ & $167.95 \pm 7.74^{\mathrm{b}}$ & $174.55 \pm 16.60^{\mathrm{b}}$ \\
\hline BUN (mg/dL) & $24.94 \pm 1.20^{\mathrm{a}}$ & $22.18 \pm 0.84^{\mathrm{a}}$ & $22.52 \pm 0.94^{\mathrm{a}}$ & $21.62 \pm 0.72^{\mathrm{a}}$ \\
\hline $\begin{array}{c}\text { Uric acid } \\
(\mathrm{mg} / \mathrm{dL})\end{array}$ & $0.63 \pm 0.12^{\mathrm{c}}$ & $0.72 \pm 0.10^{\mathrm{a}}$ & $0.62 \pm 0.11^{\mathrm{b}}$ & $0.99 \pm 0.10^{\mathrm{a}}$ \\
\hline $\begin{array}{c}\text { Total protein } \\
(\mathrm{g} / \mathrm{dL})\end{array}$ & $5.98 \pm 0.13^{\mathrm{b}}$ & $5.80 \pm 0.06^{\mathrm{a}}$ & $6.18 \pm 0.07^{\mathrm{c}}$ & $5.99 \pm 0.06^{\mathrm{b}}$ \\
\hline $\begin{array}{c}\text { Albumin (g/dL) } \\
\text { Globulin (g/dL) }\end{array}$ & $3.20 \pm 0.05^{\mathrm{c}}$ & $3.10 \pm 0.03^{\mathrm{a}}$ & $3.21 \pm 0.03^{\mathrm{c}}$ & $3.16 \pm 0.02^{\mathrm{b}}$ \\
\hline
\end{tabular}

Value with different superscripts in a row were significantly different $(\mathrm{P}<0.05)$ 
Table.3 SOD activity in serum and different organs of rats under experiments

\begin{tabular}{|c|c|c|c|c|c|}
\hline \multicolumn{2}{|c|}{ Parameters } & \multicolumn{4}{|c|}{ Treatment groups } \\
\hline & & Control & 15 ppm (T1) & $50 \mathrm{ppm}(\mathrm{T} 2)$ & 100 ppm (T3) \\
\hline $\begin{array}{l}\text { SOD } \\
\text { (U/mL) }\end{array}$ & Serum & $4.18 \pm 0.62^{a}$ & $5.33 \pm 0.48^{b}$ & $5.74 \pm 0.77^{b}$ & $5.57 \pm 0.93^{\mathrm{b}}$ \\
\hline \multirow{4}{*}{$\begin{array}{l}\text { SOD } \\
\text { (U/mg of } \\
\text { tissue) }\end{array}$} & Liver & $0.73 \pm 0.08^{b}$ & $0.66 \pm 0.06^{\mathrm{a}}$ & $0.85 \pm 0.03^{c}$ & $0.85 \pm 0.04^{\mathrm{c}}$ \\
\hline & Kidney & $0.70 \pm 0.10^{d}$ & $0.66 \pm 0.05^{\mathrm{c}}$ & $0.53 \pm 0.07^{\mathrm{a}}$ & $0.62 \pm 0.05^{b}$ \\
\hline & Intestine & $0.38 \pm 0.04^{d}$ & $0.26 \pm 0.06^{c}$ & $0.17 \pm 0.01^{\mathrm{a}}$ & $0.22 \pm 0.02^{b}$ \\
\hline & Heart & $0.42 \pm 0.11^{b}$ & $0.36 \pm 0.07^{\mathrm{a}}$ & $0.59 \pm 0.11^{\mathrm{c}}$ & $0.33 \pm 0.05^{\mathrm{a}}$ \\
\hline
\end{tabular}

Value with different superscripts in a row were significantly different $(\mathrm{P}<0.05)$

Table. 4 Catalase activity in blood and different organs of rats under experiments

\begin{tabular}{|c|c|c|c|c|c|}
\hline \multicolumn{2}{|c|}{ Parameters } & \multicolumn{4}{c|}{ Treatment groups } \\
\cline { 3 - 6 } & Control & 15 ppm (T1) & 50 ppm (T2) & 100 ppm (T3) \\
\hline $\begin{array}{c}\text { Blood } \\
\text { catalase } \\
\text { (molar/min) }\end{array}$ & Blood & $11.70 \pm 1.45^{\mathrm{c}}$ & $9.31 \pm 1.84^{\mathrm{b}}$ & $7.42 \pm 0.67^{\mathrm{a}}$ & $6.82 \pm 0.51^{\mathrm{a}}$ \\
\hline $\begin{array}{c}\text { Catalase } \\
(\mathrm{U} / \mathrm{mg} \\
\text { protein) }\end{array}$ & Liver & $17.66 \pm 5.49^{\mathrm{b}}$ & $22.40 \pm 7.55^{\mathrm{c}}$ & $12.64 \pm 1.42^{\mathrm{a}}$ & $14.48 \pm 2.7^{\mathrm{a}}$ \\
\cline { 3 - 6 } & Kidney & $44.04 \pm 8.02^{\mathrm{b}}$ & $40.80 \pm 9.20^{\mathrm{b}}$ & $42.72 \pm 5.33^{\mathrm{b}}$ & $35.15 \pm 6.93^{\mathrm{a}}$ \\
\hline & Intestine & $18.24 \pm 3.16^{\mathrm{d}}$ & $13.90 \pm 5.1^{\mathrm{c}}$ & $5.62 \pm 1.81^{\mathrm{b}}$ & $2.44 \pm 0.26^{\mathrm{a}}$ \\
\hline & Heart & $6.58 \pm 2.22^{\mathrm{c}}$ & $2.41 \pm 0.35^{\mathrm{b}}$ & $1.87 \pm 0.27^{\mathrm{ab}}$ & $1.45 \pm 0.37^{\mathrm{a}}$ \\
\hline
\end{tabular}

Note: Value with different superscripts in a row were significantly different $(\mathrm{P}<0.05)$

Table.5 GSH levels in blood and different organs of rats under experiments

\begin{tabular}{|c|c|c|c|c|c|}
\hline \multicolumn{2}{|c|}{ Parameters } & \multicolumn{4}{|c|}{ Treatment groups } \\
\cline { 3 - 6 } & C1 & T2 & T3 & T4 \\
\hline $\begin{array}{c}\text { GSH } \\
(\text { molar })\end{array}$ & Blood & $11.09 \pm 0.56^{\mathrm{c}}$ & $10.27 \pm 1.24^{\mathrm{b}}$ & $8.86 \pm 0.95^{\mathrm{a}}$ & $10.07 \pm 0.46^{\mathrm{b}}$ \\
\hline $\begin{array}{c}\text { GSH } \\
\left(\begin{array}{c}\mathrm{g} / \mathrm{mg} \text { of } \\
\text { tissue })\end{array}\right.\end{array}$ & Liver & $0.08 \pm 0.01^{\mathrm{b}}$ & $0.09 \pm 0.01^{\mathrm{b}}$ & $0.04 \pm 0.01^{\mathrm{a}}$ & $0.04 \pm 0.01^{\mathrm{a}}$ \\
\cline { 2 - 6 } & Kidney & $0.07 \pm 0.02^{\mathrm{b}}$ & $0.07 \pm 0.01^{\mathrm{b}}$ & $0.09 \pm 0.04^{\mathrm{b}}$ & $0.04 \pm 0.01^{\mathrm{a}}$ \\
& Intestine & $0.154 \pm 0.53^{\mathrm{b}}$ & $0.027 \pm 0.003^{\mathrm{a}}$ & $0.027 \pm 0.001^{\mathrm{a}}$ & $0.033 \pm 0.003^{\mathrm{a}}$ \\
\cline { 2 - 6 } & Heart & $0.01 \pm 0.003^{\mathrm{a}}$ & $0.03 \pm 0.006^{\mathrm{d}}$ & $0.02 \pm 0.001^{\mathrm{b}}$ & $0.02 \pm 0.002^{\mathrm{c}}$ \\
\hline
\end{tabular}

Value with different superscripts in a row were significantly different $(\mathrm{P}<0.05)$ 
Fig.1 The average feed consumption (g/Animal/Day) of experimental animals of different groups

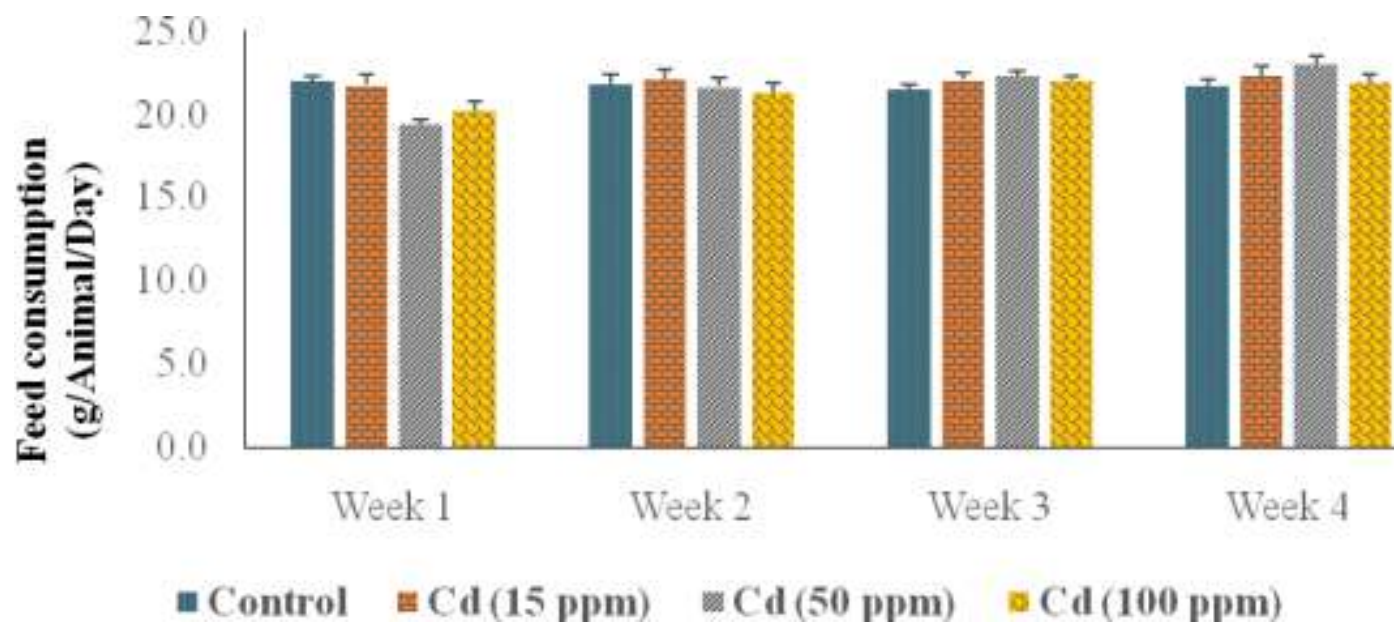

Fig.2 Body weight (g) of experimental animals of different groups

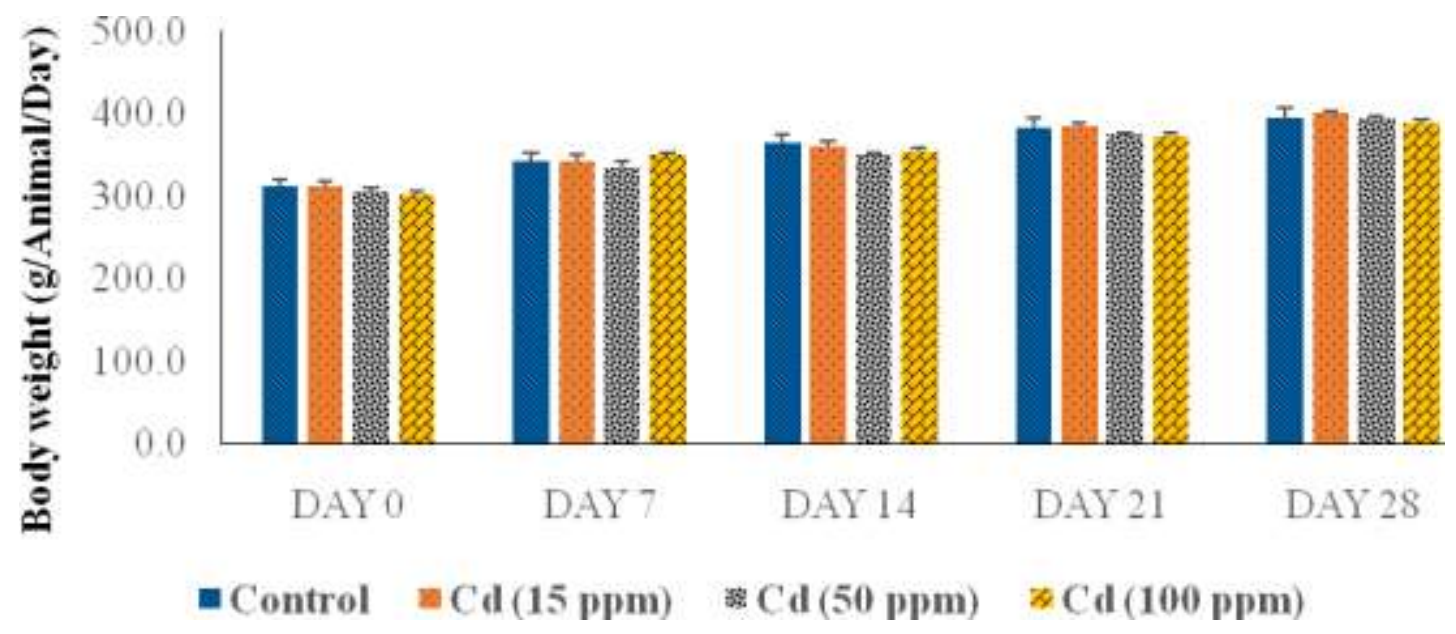

Fig.3 Plasma MDA levels $(\mathrm{nm} / \mu \mathrm{L})$ of animals under experiment

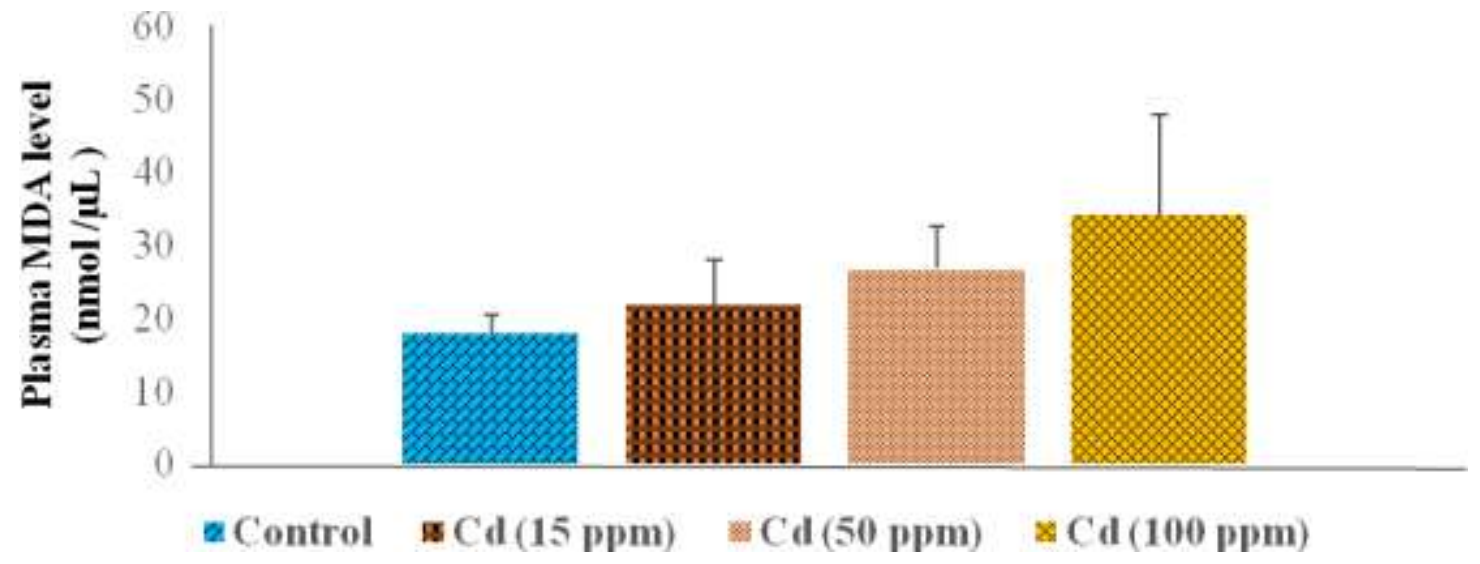


Fig.4 Microscopic changes in liver of rats of different treatment groups (H \& E, x 400)

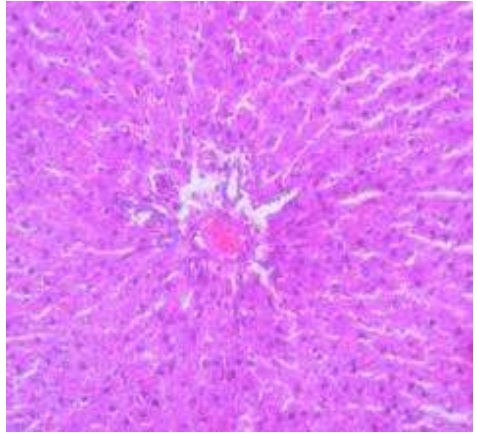

C1 group: Normal liver with hepatocytes $(\mathrm{H})$, nuclei $(\mathrm{N})$, Central vein $(\mathrm{CV})$, sinusoids (S), Hepatic artery (HA) and bile duct (BD)

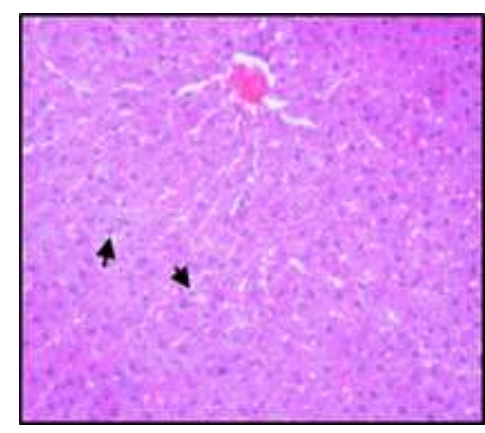

T1 group: Slight vacuolar degeneration of hepatocytes (thin arrow) with hemorrhage.

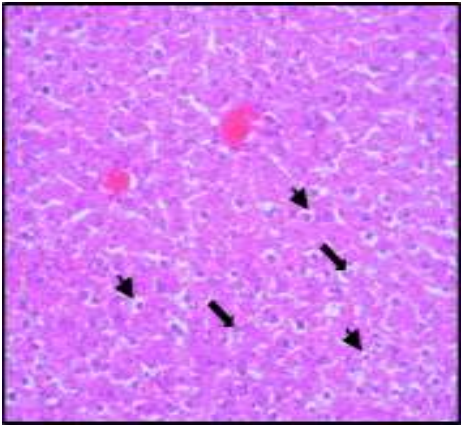

T2 group: Vacuolar degeneration (Thin arrow), widening of sinusoids, hemorrhage, pyknotic nucleus.

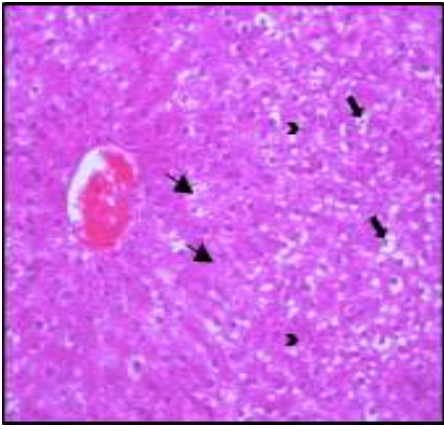

T3 group: Showing necrosis of hepatocytes (thin arrow), widening of sinusoids, fragmentation of nuclei and pyknotic nuclei.

Fig.5 Microscopic changes in kidney of rats of different treatment groups (H \& E, x400)

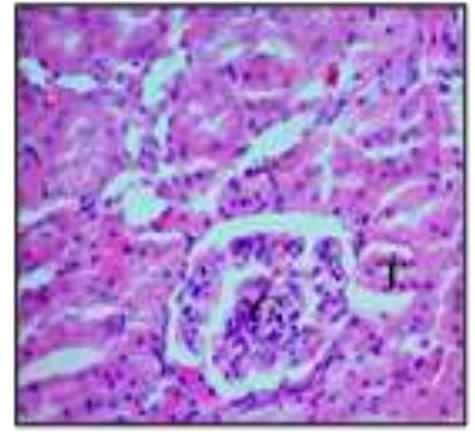

C1 group: Normal architecture of glomeruli $(\mathrm{G})$ and renal tubules $(\mathrm{T})$.

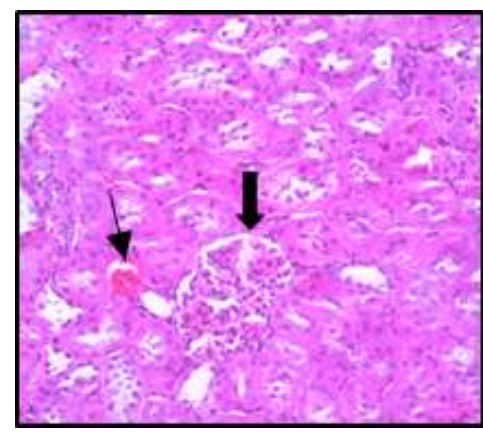

T1 group: Mild degenerative changes in renal tubular (thin arrow) with swelling of glomeruli (thick arrow).

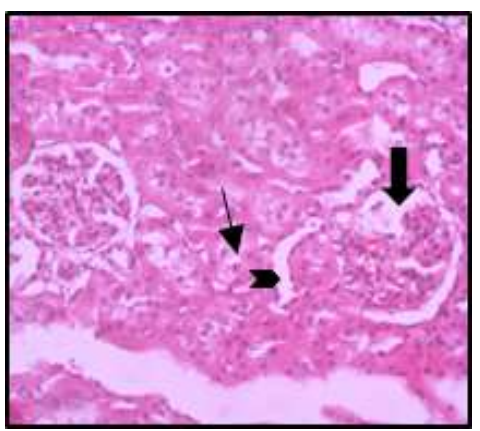

T2 group: Degenerative changes in glomeruli (thick arrow) and proximate convoluted tubules (thin arrow). Denudation of bowmen capsule segment (arrow head)

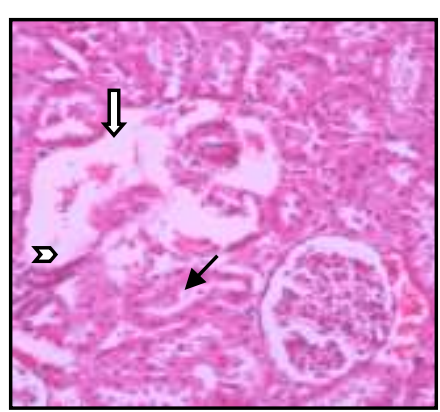

T3 group: Necrosis of glomeruli and loss of structure glomeruli (arrow), necrotic (thick hanges in proximal (thick arrow) and distal convoluted tubules, Denudation of bowmen capsule segment (arrow head). 
Fig.6 Microscopic changes in intestine of rats of different treatment groups (H \& E, x400)

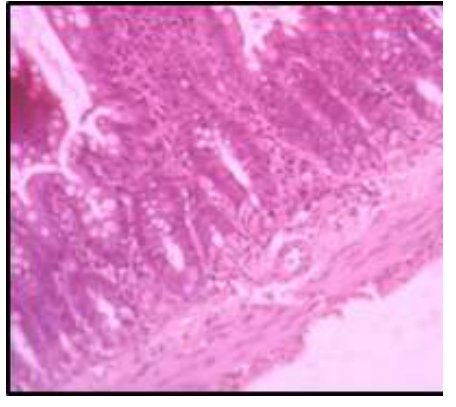

C1 group: Normal structure of intestine.

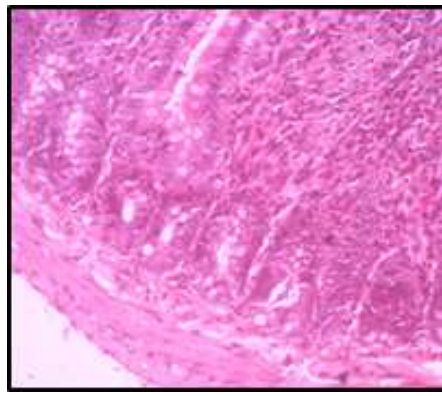

T1 group: With mild degenerative changes of villi.

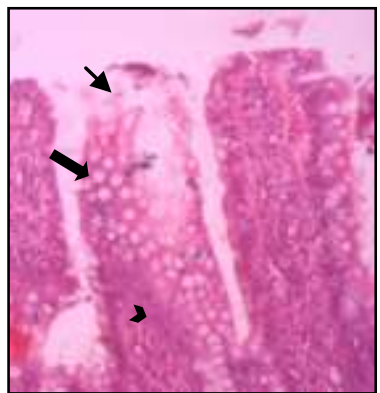

T2 group: Degenerative changes in villi (arrow head), increase in number of goblet cells (thick arrow), disruption of epithelial membrane (thin arrow).

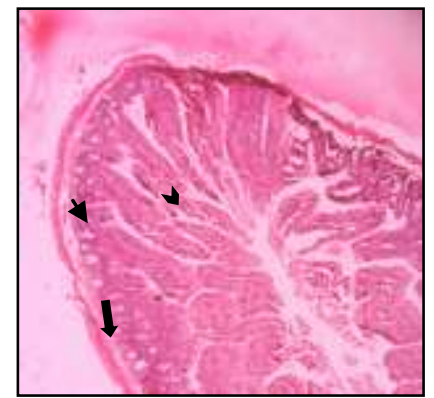

T3 group: Atrophy of intestinal glands (thin arrow) and muscularis mucosa (thick arrow), breakage of villi (arrow head).

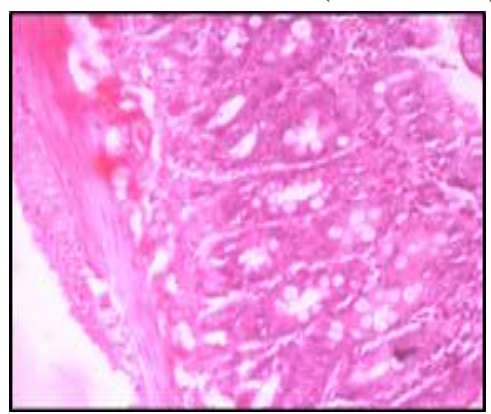

T3 group: Degeneration with loss of architecture of villi, atrophy of lamina propria and mucosa epithelium.

Fig.7 Microscopic changes in heart of rats of different treatment groups (H \& E, x400)

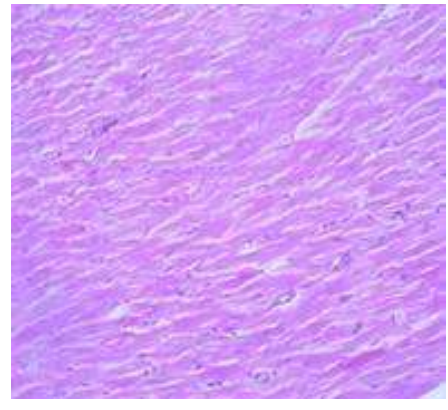

C1 group: Normal structure of cardiac muscle fibers.

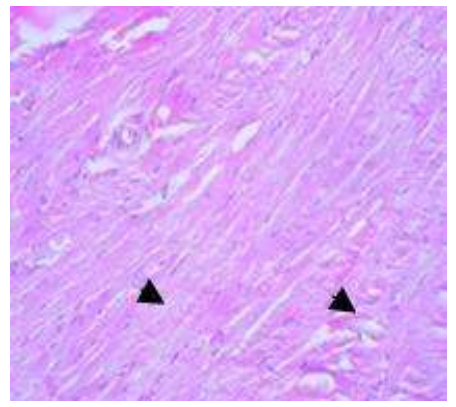

T1 group: Mild degenerative changes of cardiac muscle fibers (thin arrow).

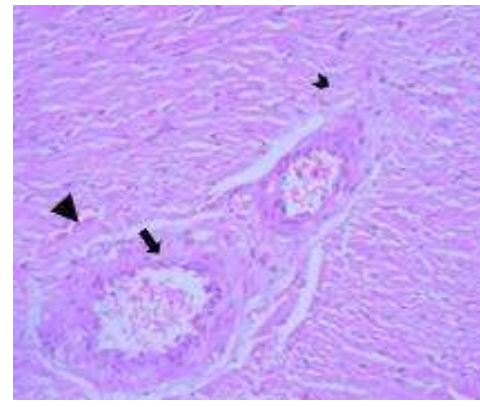

T2 group: Degenerative changes in cardiac muscle fibers (arrow head), perivascular fibrosis (thick arrow) and haemorrhagic lesions (thin arrow).

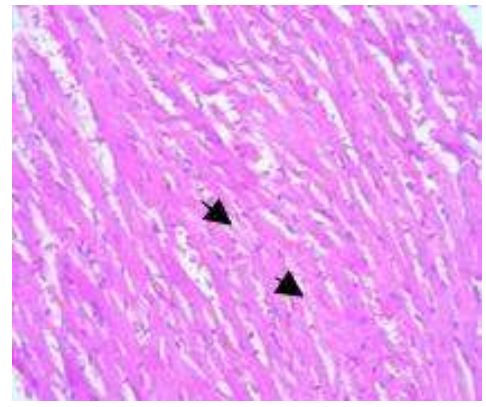

T3 group: Mild Early focal necrosis of cardiac muscle fibers (thin arrow) 
Decreased activity of SOD in major organs may be due to either the antagonistic effect of cadmium with copper and zinc, which are important metals for the activity of SOD or inactivation of SOD by cadmium induced lipid peroxidation (Tang et al., 1998). Whanger (1979) reported that the decrease in catalase activity by cadmium may be due to alterations in absorption of iron, an essential trace element required for the activity of catalase. Lipid peroxidation involves a broad spectrum of alterations in cells and the consequent degeneration of cell membranes. Free radicals and intermediate products of peroxidation are capable of damaging the integrity and altering the functions of biomembranes, which can lead to the development of many pathological processes (Shukla et al., 2000). Glutathione is an important antioxidant plays a crucial role in preventing the damage to cellular components caused by species such as free radicals and peroxides (Kaur et al., 2003). It is a tripeptide with a gamma peptide linkage between the carboxyl group of the glutamate side-chain and the amine group of cysteine. It was invented that there is a correlation between the histological observations and oxidative damage induced by $\mathrm{CdCl}_{2}$. Our results revealed that the mean level of MDA was increased significantly associated with a reduction in antioxidant defence systems that protect tissues against oxidative damage through a decrease in GSH, SOD and CAT levels in $\mathrm{CdCl}_{2}$ treated group which were dose dependent manner in majority.

The $\mathrm{CdCl}_{2}$ exposure affects the cardiovascular system via several mechanisms. It produces vascular endothelial dysfunction, reduces nitric oxide (NO) level (Nwokocha et al., 2013) and oxidative stress that cause the induction of hypertension and further exacerbates the cardio toxicity (Kukongviriyapan et al., 2014). Antioxidant defence system plays a pivotal role in organ protection. Antioxidant enzymes, such as CAT, GPx, and SOD, mitigate the toxic effects of reactive oxygen species (ROS) (Halliwell, 1989). SOD also inhibits oxidative inactivation of nitric oxide, consequently preventing peroxynitrite formation and endothelial dysfunction (Fukai et al., 2011). In our study, there was significantly decrease in levels of SOD and catalase in heart of animals exposed to medium and high level of cadmium but GSH level in heart tissue were significantly higher as compared to control which indicates protective effects to heart tissue in terms of conversion of $\mathrm{H}_{2} \mathrm{O}_{2}$ into $\mathrm{H}_{2} \mathrm{O}$ which might be the reasons for lesser effect of cadmium on heart as compared to kidney, liver and intestine. Yanez et al. (1991) reported that $\mathrm{Cd}$ exposure in rats significantly induced the levels of glutathione in heart tissue. The glutathione production in heart showed defensive mechanism to combat against toxic effect of cadmium.

The histopathological analysis revealed dose dependent damage to liver, kidney and intestine. The changes in liver morphology were might be due to accumulation of $\mathrm{Cd}$ in hepatocytes and direct cytotoxic effect of $\mathrm{Cd}$. Rikans and Yamano (2000) also reported that hepatic endothelial cells (EC) is the first cellular targets for Cd-induced hepatocellular injury and damaged EC produced local ischemia by blocking the capillary lumen and this leads a number of molecular and cellular events, which results in hepatocellular injury. In kidney and intestine the architectural alterations were caused by disturbance of membrane integrity and involvement of inflammatory mediators by Cd (Muller, 1986; Kayama et al., 1995). The histopathological alterations in heart were mild but dose dependent. Mitra et al. (2012) also observed cadmium induced alteration in heart of rats. Yazihan et al. (2011) reported Cd induced caspase activated apoptosis with degenerative changes in cardiac muscle fibers. In general, 
histopathological changes in liver, kidney, heart and intestine were more or remarkable at high level of exposure.

In conclusion, cadmium produced remarkable alterations in blood biochemistry along with ultrastructural changes in liver, kidney, heart and intestine which were either through direct toxicity to organs or oxidative stress in rats following sub-acute exposure at $100 \mathrm{ppm}$ level. This level of cadmium exposure to rats produced classical oxidative stress mediated toxicity and which can be further used for related toxicological studies.

\section{References}

Adiele, R. C., Stevens, D. and Kamunde, C. 2012. Differential inhibition of electron transport chain enzyme complexes by cadmium and calcium in isolated rainbow trout (Oncorhynchus mykiss) hepatic mitochondria. Toxicological Science. 127(1): 110-19.

Aebi, H., Sonja, R., Bernhard, S. and Frantisek, S. 1974. Heterogeneity of erythrocyte catalase, isolation and characterization of normal and variant erythrocyte catalase and their subunits. European Journal of Biochemistry. 48(1): 137-145.

Ashour, T. H. 2014. Preventative effects of caffeic acid phenyl ester on cadmium intoxication induced hematological and blood coagulation disturbances and hepatorenal damage in rats. ISRN Haematology. 764754 (2014): 1-7.

Bradford, M. M. 1976. A rapid and sensitive method for the quantitation of microgram quantities of protein utilizing the principle of protein-dye binding. Analytical Biochemistry. 72(2): 248-254.

Chan, H. M., Zhu, L., Zhong, R., Grant, D., Goyer, R. A. and Cherian, M. G. 1993. Nephrotoxicity in rats following liver transplantation from cadmium exposed rats. Toxicology and Applied Pharmacology. 123: 89-96.

Cuypers, A., Plusquin, M., Remans, T., Jozefczak, M., Keunen, E., Gielen, H., Opdenakker, K., Nair, A. R., Munters, E., Artois, T. J., Nawrot, T., Van gronsveld, J. and Smeets, K. 2010. Cadmium stress: an oxidative challenge. Biometals. 23(5): 927-940.

Dudley, R. E., Gammal, L. M and Klaassen, C. D. 1985. Cadmium induced hepatic and renal injury in chronically exposed rats: likely role of cadmiummetallothionein in nephrotoxicity. Toxicology and Applied Pharmacology. 77(3): 414-426.

Ellman, G. 1959. Tissue sulfhydryl groups. Archives of Biochemistry and Biophysics. 82(1): 70-77.

Everett, C. J. and Frithsen, I. L. 2008. Association of urinary cadmium and myocardial infarction. Environmental Research. 106 (2): 284-286.

Fay, R. M. and Mumtaz, M. M. 1996. Development of a priority list of chemical mixtures occurring at 1188 hazardous waste sites, using the HazDat database. Food Chemical Toxicology. 34(11): 1163-1165.

Fowler, B. A. 2009. Monitoring of human populations for early markers of cadmium toxicity: a review. Toxicology and Applied Pharmacology. 238(3): 294-300.

Fukai, T. and Ushio-Fukai, M. 2011. Superoxide dismutase: role in redox signaling, vascular function, and diseases. Antioxidant and Redox Signaling. 15(6): 1583-1606.

Gill, T.S. and Epple, N.1993. Stress-related changes in the heamatological profile of the American Eel Anguilla rostrata. Ecotoxicology and Environmental Safety. 25(2): 227-233. 
Halliwell B. 1989. Free radicals, reactive oxygen species and human disease: a critical evaluation with special reference to atherosclerosis. British Journal of Experimental Pathology. 70(6): 737757.

Horiguchi, H., Oguma, E. and Fujio Kayama, F. 2011. Cadmium induces anaemia through interdependent progress of haemolysis, body iron accumulation, and insufficient erythropoietin in production in rat. Toxicology Science. 122(1): 198-210.

Kanter, M., Aksu, B., Akpolat, M., Tarladacalisir, Y. T; Aktas, C. and Uysal, H. 2009. Vitamin E protects against oxidative damage caused by cadmium in the blood of rats. European Journal of General Medicine. 6(3): 154160.

Kaur, P., Yousuf, S., Ansari, M. A., Siddique, A., Ahmad, A. S. and Islam F. 2003. Tellurium-induced dose-dependent impairment of antioxidant status: differential effects in cerebrum, cerebellum, and brainstem of mice. Biological Trace Element Research. 94: 247-258.

Kayama, F., Yoshida, T., Elwell, M. R. and Luster, M. I. 1995. Cadmium induced reanal damage and proinflammatory cytokines: possible role of IL-6 in tubular epithelial cell regeneration. Toxicology and Applied Pharmacology. 134(1): 23-34.

Knox, W. E. and Greengard, O. 1965. The regulation of some enzymes of nitrogen metabolism: an introduction to enzyme physiology. Advanced Enzyme Regulations 3: 247-313.

Kukongviriyapan, U., Pannangpetch, P., Kukongviriyapan, V., Donpunha, W., Sompamit, K. and Surawattanawan P. 2014. Curcumin protects against cadmium-induced vascular dysfunction, hypertension and tissue cadmium accumulation in mice. Nutrients. 6(3):1194-1208.

Limaye, D. A. and Shaikh, Z. A. 1999. Cytotoxicity of cadmium and characteristics of its transport in cardiomyocytes. Toxicology and Applied Pharmacology. 154(1): 59-66.

Luna, L. G. 1968. Routine staining procedures: Hematoxylin and eosin stains. In: Manual of histologic staining methods of the Armed Forces Institute of Pathology. $3^{\text {rd }}$ edn. McGraw-Hill, New York. pp: 32-39.

Marklund, S. and Marklund, G. 1974. Involvement of the superoxide anion radical in the autooxidation of pyrogallol and a convenient assay for superoxide dismutase. European Journal of Biochemistry. 47(3): 469474.

Mitra, E., Ghosh, A. K., Ghosh, D., Mukherjee, D., Chattopadhyay, A., Dutta, S., Pattari, S. K. and Bandyopadhyay, D. 2012. Protective effect of aqueous curry leaf (Murraya koenigii) extract against cadmiuminduced oxidative stress in rat heart. Food and Chemical Toxicology. 50 (5): 1340-1353.

Muller, L. 1986. Consequences of cadmium toxicity in rat hapetocytes: Mitochondrail disfunction and lipid peroxidation. Toxicology. 40(3): 285295.

Nair, A. R., DeGheselle, O., Smeets, K., Van Kerkhove, E. and Cuypers, A. 2013 Cadmium-induced pathologies: where is the oxidative balance lost (or not)? International Journal of Molecular Science. 14(3): 6116-6143.

Nwokocha, C. R., Baker, A., Douglas, D; McCalla, G., Nwokocha, M. and Brown, P. D. 2013. Apocynin ameliorates cadmium-induced hypertension through elevation of endothelium nitric oxide synthase. 
Cardiovascular Toxicology. 13(4): $357-$ 363.

Ognjanovic, B. I., Pavlovic, Z., Maletic, S. D., Zikic, R. V., Stajn, A. S., Radojicic, R. M., Saicic, Z. S. and Petrovic, V. M. 2003. Protective influence of vitamin $E$ on antioxidant defense system in the blood of rats treated with cadmium. Physiol. Res. 52: 563-570.

Patra, R. C., Rautray, A. K. and Swarup, D. 2011. Oxidative Stress in Lead and Cadmium Toxicity and Its Amelioration. Veterinary Medicine International. 1: 9-15.

Pawaiya, R. V. S., Charan, K., Manna, J. 1998. Cadmium toxicity in rabbit's hematological and pathological study. Indian Journal Veterinary Pathology. 22(2): 109-114.

Peters, J. L., Perlstein, T. S., Perry, M. J., McNeely, E. and Weuve, J. 2010. Cadmium exposure in association with history of stroke and heart failure. Environmental Research. 110 (2): 199206.

Quig D. 1998. Cysteine metabolism and metal toxicity. Alternative Medicine Reveiw. 3(4): 262-270.

Rana, S. V., Rekha, S., Seema, V. 1996. Protective effects of few antioxidants on liver function in rats treated with cadmium and mercury. Indian Journal of Experimental Biology. 34(2): 177179.

Rikans, L. E. and Yamano, T. 2000. Mechanisms of cadmium-mediated acute hepatotoxicity. Journal of Biochemistry and Molecular Toxicology. 14(2): 110-117.

Satarug, S., Garrett, S. H., Sens, M. A. and Sens, D. A. 2010. Cadmium, environmental exposure and health outcomes. Environmental Health Perspective. 118(2): 182-190.

Shukla, A., Shukla, G. S. and Srimal, R. C. 1996. Cadmium-induced alterations in blood-brain barrier permeability micro vessel antioxidant potential in rat. Human and Experimental Toxicology. 15(5): 400-405.

Shukla, G. S., Shukla, A., Potts, R. J., Osier, M. and Hart, B. A. 2000. Cadmiummediated oxidative stress in alveolar epithelial cells induces the expression of gammaglutamylcysteine synthetase catalytic subunit and glutathione-Stransferase alpha and pi isoforms: potential role of activator protein-1. Cell Biology and Toxicology. 16: 347-362.

Sinha, M., Manna, P. and Sil, P. C. 2008. Taurine protects the antioxidant defense system in the erythrocytes of cadmium treated mice. BMB Report. 41(9): 657663.

Siu, E. R., Mruk, D. D., Porto, C. S. and Cheng, C. Y. 2009. Cadmium-induced testicular injury. Toxicology and Applied Pharmacology. 238(3): 240249.

Snedecor, G. W. and Cochran, W. G. 1982. Statistical Methods. $8^{\text {th }}$ edn. Iowa state university press, Ames, Iowa.

Tandon, S. K., Singh, S; Prasad, S., Khandekar, K., Dwivedi, V. D., Chatterjee, M. and Mathur, N. 2003. Reversal of cadmium induced oxidative stress by chelating agent, antioxidant or their combination in rat. Toxicology Letters. 145(3): 211-217.

Tang, W., Sadovic, S. and Shaikh, Z. A. 1998. Nephrotoxicity of cadmium metallothionein protection by zinc and role of glutathione. Toxicology and Applied Pharmacology. 151(2): 276-82.

Tung, H. T., Cook, F. W., Wyatt, R. D., Hamilton, P. B., 1975. The anaemia caused by aflatoxin. Poultry Science. 54(6): 1962-1969.

Valko, M., Morris, H. and Cronin, M. T. D. 2015. Metals, toxicity and oxidative stress. Current Medicinal Chemistry. 12(10): 1161-1208. 
Waalkes, M. P. 2000. Cadmium carcinogenesis in review. Journal of Inorganic Biochemistry. 79(4): 241244.

Waltkins, J. A., Kawanishi, S. and Caughey, W. S. 1985. Autoxidation reactions of hemoglobin a free from other red cell components: a minimal mechanism. Biochemical and Biophysical Research Communications. 132(2): 742-748.

Webb, M. 1986. Role of metallothionein in cadmium metabolism. In Cadmium Vol. 80, Handbook of Experimental Pharmacology (E. C. Foulkes, Ed.), pp. 281- 395.

Whanger, P. D. 1979. Cadmium effects in rats on tissue iron, selenium and blood pressure. Environmental Health Perspective. 28: 115-118.

WHO 1992. Environmental health criteria 134, Cadmium. Cited as: http://www.inchem.org/documents/ehc/ ehc/ehc134.htm, 20, July, 2018.
Yanez, L., Carrizales, L., Zanatta, M. T., Mejia, J. J., Batres, L. and Diaz-Barriga, F. 1991. Arsenic-cadmium interaction in rats: toxic effects in the heart and tissue metal shifts. Toxicology. 67(2): 227- 234.

Yazihan, N., Kocak, M. K., Akcil, E., Erdem, O., Sayal, A., Guven. C. and Akyurek, N. 2011. Involvement of galectin-3 in cadmium-induced cardiac toxicity. Anadolu Kardiyoloji Dergisi. 11(6): 479-484.

Yuan, G., Dai, S. and Yin, Z. 2014. Toxicological assessment of combined lead and cadmium: acute and subchronic toxicity study in rats. Food and Chemical Toxicology. 65: 260-268.

Zalups, R. K. and Ahmad, S. 2003. Molecular handling of cadmium in transporting epithelia. Toxicology and Applied Pharmacology. 186(3): 163-188.

\section{How to cite this article:}

Rao, S.S., C.N. Makwana, U.D. Patel, V.C. Ladumor, H.B. Patel and Modi, C.M. 2019. Oxidative Stress Mediated Dose-Dependent Pathophysiological Alterations in Liver, Kidney, Heart and Intestine of Rats Exposed to Different Levels of Cadmium Chloride. Int.J.Curr.Microbiol.App.Sci. 8(01): 393-409. doi: https://doi.org/10.20546/ijcmas.2019.801.041 